\title{
SINTESIS DAN KARAKTERISASI HIDROKSIAPATIT TULANG IKAN BAUNG (Hemibagrus nemurus $s p$.) SEBAGAI KANDIDAT IMPLAN TULANG
}

\author{
Achmad Fitriadi Akbar, Filza Qurrota 'Aini, Browi Nugroho, Sari Edi Cahyaningrum* \\ Jurusan Kimia, Fakultas Matematika dan Ilmu Pengetahuan Alam, Universitas Negeri Surabaya \\ *email : saricahyaningrum@unesa.ac.id
}

Received 15 Oktober 2021

Accepted 30 November 2021

\begin{abstract}
Abstrak
Tulang ikan Baung memiliki komposisi kalsium sebesar 30,93\% dengan rendemen sebesar $27,77 \%$. Hidroksiapatit merupakan material yang banyak diaplikasikan secara luas untuk regenerasi tulang, implan tulang dan gigi, serta ortopedi. Penelitian ini bertujuan untuk mengetahui pengaruh waktu kalsinasi tulang ikan Baung menggunakan instrumen XRD dan FTIR. Instrumen XRD digunakan untuk mengetahui karakteristik fisika dan FTIR digunakan untuk mengetahui karakteristik kimia. Pada penelitian ini menggunakan metode sol-gel, karena mampu meningkatkan kristalinitas dari HAp dan mengatur komposisi, menghasilkan lapisan homogen, efektif dan murni bagi sintesis hidroksiapatit dalam fasa nano. Rendemen yang diperoleh pada proses kalsinasi sebesar $61,8 \%, 58,5 \%$ dan $62 \%$. Hidroksiapatit yang diperoleh kemudian dikaraterisasi kimia menggunakan instrumen FTIR menunjukkan adanya gugus fungsi $\mathrm{PO}_{4}{ }^{3-}$ dan $\mathrm{CO}_{3}{ }^{2-}$ Sedangkan instrumen XRD menunjukkan fasa hidroksiapatit dan fasa pirofosfat Hidroksiapatit dikarakterisasi secara fisika memperoleh derajat kristanilitas sebesar 85,6\%, 63,45\%, dan 74,24\%.
\end{abstract}

Kata kunci: Tulang ikan Baung, hidroksiapatit, kristanilitas

\begin{abstract}
Baung fish bones have a calcium composition of $30.93 \%$ with a yield of $27.77 \%$. Hydroxyapatite is a material that is widely applied for bone regeneration, bone and dental implants, and orthopedics. This study aimed to determine the effect of calcination time of Baung fishbone using XRD and FTIR instruments. XRD instrument was used to determine physical characteristics and FTIR was used to determine chemical characteristics. In this study, the sol-gel method was used, because it was able to increase the crystallinity of HAp and adjust the composition, resulting in a homogeneous, effective and pure layer for the synthesis of hydroxyapatite in the nanophase. The yields obtained in the calcination process were $61.8 \%, 58.5 \%$ and $62 \%$. The hydroxyapatite obtained was then chemically characterized using the FTIR instrument showing the presence of the $\mathrm{PO}_{4}{ }^{3-}$ and $\mathrm{CO}_{3}{ }^{2-}$ functional group. While the XRD instrument showed that the hydroxyapatite and pyrophosphate phases were physically characterized to obtain crystallinity degrees of $85.6 \%, 63.45 \%$, and $74.24 \%$.
\end{abstract}

Keywords: Baung fish bone, hydroxyapatite, crystallinity 


\section{Pendahuluan}

Penggunaan biomaterial sebagai pengganti tulang perlu diperhatikan, diantaranya mudah diperoleh, biokompatibel, bioaktif dan tidak beracun. Diantara biomaterial tersebut adalah hidroksiapatit (Sulistioso, et al., 2012). Hidroksiapatit adalah salah satu jenis material apatit yang memiliki rumus kimia $\mathrm{Ca}_{10}\left(\mathrm{PO}_{4}\right)_{6} \mathrm{OH}_{2}$. Hidroksiapatit termasuk dalam biokeramik yang belakangan dikaji secara intesif terkait pengaplikasian dalam bidang medis (Anggresani, et al., 2019).

Selama bertahun-tahun, hidroksiapatit telah dipelajari dan diaplikasikan secara luas sebagai bahan dasar pembuatan implan (Amin \& Ulfah, 2017) karena hidroksiapatit termasuk salah satu penyusun jaringan keras (hard tissue) pada tulang, gigi dan dentin di dalam tubuh manusia (Haruda, et al., 2016). Kemiripannya seperti tulang manusia terbukti mempunyai sifat biokompatibel dengan tulang dan gigi manusia (Amin \& Ulfah, 2017). Selain itu, hidroksiapatit juga diaplikasikan sebagai material regenerasi tulang dan bidang ortopedi. Pengaplikasiaan hidroksiapatit didasarkan pada sifat hidroksiapatit yaitu bioresorbabel, osteokonduktif, bioaktif, biokompatibel, tidak beracun (Anggresani, et al., 2019), serta ramah lingkungan (Nurmanta, et al., 2021).

Sifat hidroksiapatit yang biokompatibel akan membuat diterima pada jaringan tubuh dan membuat hidroksiapatit sebagai salah satu prekursor pembuatan biomaterial yang mampu mengobati maupun mengganti jaringan organ atau fungsi dari tubuh serta digunakan sebagai material pendukung imobilisasi enzim (Saleha, et al., 2015). Sedangkan bioaktif berarti memiliki kemampuan untuk terikat secara kimia dengan jaringan hidup manusia (Anggresani, et al., 2019). Karakteristik ini memperlihatkan adanya material hidroksiapatit yang mampu berikat pada jaringan keras sehingga terdapat respon biologis spesifik (Afifah \& Cahyaningrum, 2020). Sedangkan bioresorbable merupakan kemampuan jaringan biologis utuk menyerap material. Osteokonduktif merupakan kemampuan material untuk merangsang sel osteoblas dalam jaringan keras manusia (Anjarsari, et al., 2016).

Hidroksiapatit cenderung sukar larut pada in vivo serta dapat membentuk ikatan osteogenesis. Kandidat implan dalam jaringan tubuh manusia harus memilki satu atau lebih dari sifat tersebut. Dengan memiliki sifat-sifat tersebut, pembentukan jaringan fibrosa antara implan dan jaringan keras akan sangat baik, serta mampu menjalin ikatan langsung dengan tulang host (Amin \& Ulfah, 2017), dimana ketika hidroksiapatit masuk ke dalam tubuh, akan terjadi peningkatan fiksasi implan pada jaringan sekitarnya akibat terbentuknya lapisan carbonat apatit (Rahmawati, et al., 2020).

Sintesis hidroksiapatit secara luas dilakukan dengan memanfaatkan sumber kalsium alami. Sumber kalsium alami yang telah dipakai diantaranya batu kapur, cangkang kepiting, tulang sapi (Afifah \& Cahyaningrum, 2020), dan tulang ikan. Penelitian ini mengacu pada pemanfaatan tulang ikan sebagai sumber kalsium hidroksiapatit.

Tulang ikan adalah limbah terbesar dalam industri pengolahan ikan. Pada dasarnya, tulang ikan adalah bagian dari ikan yang mempunyai banyak manfaat. Tetapi pemanfaatan tulang masih belum optimal. Hal tersebut mendukung pemikiran alternatif dalam meningkatkan daya guna tulang serta menaikkan nilai ekonomisnya (Zein, et al., 2020). Memanfaatkan biowaste berbahan dasar ikan ini berpotensi mengurangi masalah lingkungan dan mendukung keberlanjutan pembangunan lingkungan. Tulang ikan adalah zat kompleks yang terbuat dari HAP berkarbonasi, kolagen tipe-1, protein non-kolagen, dan air (Surya, et al., 2021). Tulang memiliki kandungan kalsium yang paling melimpah dalam tubuh ikan. Material utama penyusun tulang ikan meliputi kalsium fosfat dan karbonat. 
Tulang ikan mengandung kalsium setidaknya $14 \%$ dari total susunan tulang. 60-70 \% Kompleks kalsium fosfat mudah diserap tubuh (Trilaksani, et al., 2006).

Ikan Baung (Hemibagrus Nemurus Sp.) adalah komoditas popular di perairan Indonesia, memiliki nilai pasar yang tinggi terutama di kawasan kalimantan dan Sumatera. Ikan ini termasuk dalam ikan yang hidup didasar perairan payau terbentang dari hulu hingga hilir sungai. Di Kalimantan Selatan, ikan ini menjadi komoditas ikan yang biasa di konsumsi masyarakat (Komari, et al., 2013). Tulang ikan Baung mengandung 24,\% protein, $56,1 \%$ kalsium dan $32 \%$ fosfor. Dalam ukuran nano kalsium tulang ikan Baung memiliki $89,1 \%$ kalsium dan $9,8 \%$ fosfor. Dengan kandungan tersebut, tulang ikan Baung merupakan bahan potensial untuk dijadikan bahan dasar biomaterial penyusun kalsium dan nano kalsium (Sumarto, et al., 2021).

Dalam sintesis hidroksiapatit dapat menggunakan 2 metode, yaitu metode kering dan metode basah (Sulistioso, et al., 2012). Contoh dari metode basah diantaranya metode sol-gel dan metode pengendapan basah. Sedangkan metode kering diantaranya metode kalsinasi. Pada penelitian yang dilakukan, menggunakan metode sol-gel. Metode sol-gel merupakan metode yang lebih disarankan untuk mendapatkan fase nano dari hidroksiapatit. Metode ini dipercaya mampu meningkatkan kristalinitas dari hidroksiapatit, menghasilkan lapisan homogen, efektif dan murni untuk sintesis hidroksiapatit dalam fase nano (Sidiqa, et al., 2012). Selain itu, kelebihan dari metode sol gel diantaranya berlangsung pada suhu rendah, pelaksanaannya mudah, biayanya murah serta dapat diaplikasikan pada semua kondisi (Sumarto, et al., 2021).

Beberapa investigasi telah menunjukkan bahwa HAp yang diperoleh dari sumber alami ini lebih bioaktif dan memiliki respons yang lebih dinamis terhadap lingkungan dan aktivitas metabolisme yang lebih baik dibandingkan dengan sintetis. Selanjutnya, ada gugus sitrat dan karbonat serta umumnya sedikit strontium, magnesium, natrium, dan kalium dalam komposisi kimia HAp alami. Juga rasio kalsium/fosfor dalam HAp alami umumnya lebih banyak daripada apatit sintetis bahan. Dengan demikian, HAp alami lebih sesuai untuk aplikasi medis (Esmaeilkhanian, et al., 2019).

Berdasarkan penelitian sebelumnya sintesis dan karakterisasi hidroksiapatit dari limbah tulang ikan dengan metode sol gel dihasilakn spektra FTIR yang menunjukkan gugus $\mathrm{PO}_{4}{ }^{3-}$ dan $\mathrm{OH}^{-}$. Gugus $\mathrm{PO}_{4}{ }^{3-}$ terdiri dari 4 luas serapan yaitu $1092,57 \mathrm{~cm}-1, \quad 635,53 \mathrm{~cm}^{-1}, \quad 603,26 \mathrm{~cm}^{-1}$ dan $570,73 \mathrm{~cm}^{-1}$. Sedangkan gugus hidroksil $(\mathrm{OH})$ melaporkan munculnya hidroksiapatit pada serapan di daerah $3637,37 \mathrm{~cm}^{-1}$. Selanjutnya karakterisasi dengan XRD menunjukkan munculnya fasa hidroksiapatit pada sudut $2 \Theta 32,051$, 32,469 dan 33,187 (Marliana, et al., 2015). Oleh karena itu, penelitian ini dilakukan dengan metode sol gel lalu dikarakterisasi menggunakan instrumen X-Ray Diffraction (XRD) untuk mengetahui fasa dan derajat kristalinitas dan Fourier Transform Infrared (FTIR) untuk mengetahui gugus fungsi yang muncul.

\section{Metode Penelitian}

\section{Alat dan bahan}

Peralatan yang digunakan dalam penelitian ini diantaranya adalah beaker glass $100 \mathrm{~mL}$, kaca arloji, gelas ukur 50 $\mathrm{mL}$, pipet tetes, oven, tanur, Instrumen FTIR, Instrumen XRD, thermometer, magnetic stirrer, mortal alu, ayakan 100 mesh, hot plate, spatula, neraca analitik stopwatch dan buret. Bahan yang digunakan dalam penelitian ini diantaranya adalah tulang ikan Baung, larutan $\mathrm{H}_{3} \mathrm{PO}_{4}$, aquades, aseton, $\mathrm{NH}_{4} \mathrm{OH}$ dan etanol $96 \%$. 
Preparasi dan Kalsinasi Tulang Ikan Baung

Tulang ikan Baung direbus sebanyak 3 $\mathrm{Kg}$ dalam suhu $80^{\circ} \mathrm{C}$ kurang lebih 30 menit. Selanjutnya, dilakukan pencucian dengan air lalu aquades terhadap daging yang masih menempel. Kemudian merendam tulang ikan menggunakan larutan aseton dengan waktu 3x24 jam, pelarut akan diganti 1x24 jam sekali, lalu tulang ikan Baung di jemur dibawah sinar matahari. Kemudian, tulang ikan Baung dikalsinasi menggunakan tanur pada suhu $900^{\circ} \mathrm{C}$ dengan variasi waktu kalsinasi 2,3 dan 4 jam. selanjutnya digerus dan diayak dengan ayakan ukuran 100 mesh.

\section{Sintesis Hidroksiapatit Tulang Ikan Baung dengan Metode Sol Gel}

Serbuk $\mathrm{CaO}$ yang didapatkan dilarutkan pada $25 \mathrm{~mL}$ etanol 96\%, kemudian ditambahkan $25 \mathrm{~mL}$ larutan $\mathrm{H}_{3} \mathrm{PO}_{4} 80 \%$ yang dimasukkan ke dalam biuret. Sampel yang telah dilarutkan pada etanol $96 \%$ ditetesi perlahan dengan $\mathrm{H}_{3} \mathrm{PO}_{4}$, dipanaskan pada suhu $37^{\circ} \mathrm{C}$ dan diaduk dengan magnetic stirrer pada kecepatan 300 rpm, kemudian sampel dilakukan pemanasan diatas penangas dengan waktu 1 jam pada suhu $60^{\circ} \mathrm{C}$. Kemudian didiamkan kurang lebih 1x24 jam. Setelah didiamkan kemudian ditambahkan $\mathrm{NH}_{4} \mathrm{OH}$ hingga $\mathrm{pH}$ 10. Selanjutnya sampel dilakukan pengadukan menggunakan magnetic stirrer hingga sampel menjadi gel. Sampel yang telah berbentuk gel di oven dengan suhu $105^{\circ} \mathrm{C}$ dalam waktu 12 jam. kemudian, hasil oven di furnace dengan suhu $900{ }^{\circ} \mathrm{C}$ dengan variasi waktu kalsinasi 2, 3 dan 4 jam. Selanjutnya di karakterisasi dengan FTIR dan XRD.

\section{Hasil dan Pembahasan}

\section{Preparasi dan Kalsinasi Tulang Ikan Baung}

Preparasi dimulai dengan pemisahan antara tulang dengan daging yang menempel. Tulang ikan Baung direbus kurang lebih $3 \mathrm{~kg}$ dalam suhu $80^{\circ} \mathrm{C}$ selama 30 menit. Proses perebusan bertujuan untuk mengilangkan daging maupun lemak yang masih tertinggal. Setelah itu, dilakukan pembersihan dengan aquades pada daging yang menempel guna memastikan daging yang menempel telah hilang. Kemudian merendam tulang ikan menggunakan larutan aseton dengan waktu 3x24 jam, pelarut akan diganti 1×24 jam sekali. Perendaman dengan aseton bertujuan untuk mengubah warna tulang ikan menjadi putih serta mampu menghilangkan lemak yang masih menempel (Wahdah, et al., 2014). Selanjutnya, tulang ikan dikeringkan dibawah sinar matahari. Tulang ikan Baung yang telah dijemur kemudian dibagi menjadi 3 variasi dengan massa 10 gram setiap variasi. Kemudian tulangg ikan Baung di kalsinasi dengan menggunakan furnace suhu $900{ }^{\circ} \mathrm{C}$ dengan variasi waktu kalsinasi 2, 3 dan 4 jam.. Kalsinasi berjalan dengan proses penguraian (dekomposisi). Berawal dari suhu $250^{\circ} \mathrm{C}$ terjadi penguapan air, kemudian pada suhu dibawah $450^{\circ} \mathrm{C}$ komponen organik yang terkandung dalam tulang sapi akan mengalami oksidasi. Pada suhu sekitar $540^{\circ} \mathrm{C}$ akan terjadi proses penguraian $\mathrm{MgCO}_{3}$ menjadi $\mathrm{MgO}$ dan $\mathrm{CO}_{2}$, kemudian pada suhu $900^{\circ} \mathrm{C}$ terjadi penguraian $\mathrm{CaCO}_{3}$ menjadi $\mathrm{CaO}$ dan $\mathrm{CO}_{2}$ (Kim, et al., 1991).

Tulang ikan Baung sebelum di kalsinasi berwarna putih tulang, sedangkan setelah di kalsinasi berwarna putih pucat. Tulang ikan juga mengalami perubahan massa, variasi kalsinasi 2 jam memperoleh rendemen $61,8 \%$, variasi kalsinasi 3 jam menghasilkan rendemen $58,5 \%$ dan variasi kalsinasi 4 jam memperoleh rendemen $62 \%$. Perubahan warna dan berat pada tulang selama proses kalsinasi terjadi karena dekomposisi dari zat organik dan hilangnya komposisi air didalam tulang (Haruda, et al., 2016). Selanjutnya digerus dan diayak ukuran 100 mesh. 
Sintesis Hidroksiapatit dengan Metode Sol Gel

$\mathrm{CaO}$ yang didapatkan dilarutkan pada $25 \mathrm{~mL}$ etanol 96\%, kemudian ditambahkan $25 \mathrm{~mL}$ larutan $\mathrm{H}_{3} \mathrm{PO}_{4} \quad 80 \%$ yang dimasukkan ke dalam biuret. Sampel yang telah dilarutkan pada etanol $96 \%$ ditetesi perlahan dengan $\mathrm{H}_{3} \mathrm{PO}_{4}$, dipanaskan pada suhu $37^{\circ} \mathrm{C}$ dan diaduk dengan magnetic stirrer pada kecepatan $300 \mathrm{rpm}$, kemudian sampel dilakukan pemanasan diatas penangas dengan waktu 1 jam pada suhu $60^{\circ} \mathrm{C}$. Kemudian didiamkan kurang lebih 1x24 jam. Setelah didiamkan kemudian ditambahkan $\mathrm{NH}_{4} \mathrm{OH}$ hingga $\mathrm{pH} 10$. Selanjutnya sampel dilakukan pengadukan menggunakan magnetic stirrer hingga sampel menjadi gel. Sampel yang telah berbentuk gel di oven dengan suhu $105^{\circ} \mathrm{C}$ dalam waktu 12 jam. kemudian, hasil oven di furnace dengan suhu $900{ }^{\circ} \mathrm{C}$ dengan variasi waktu kalsinasi 2, 3 dan 4 jam. Proses tersebut menghasilkan kristal berwarna putih.

\section{Fourier Transformed Infrared (FTIR)}

Pada penelitian ini memiliki tujuan karakterisasi secara kimia, dimana karakterisasi ini dilakukan untuk menemukan gugus fungsi yang terdapat pada hidroksiapatit tulang ikan Baung. Proses ini menggunakan instrumen FTIR guna mengidentifikasi jenis vibrasi ikatan atom dalam suatu gugus fungsional tertentu pada bilangan gelombang 4.000$500 \mathrm{~cm}^{-1}$.

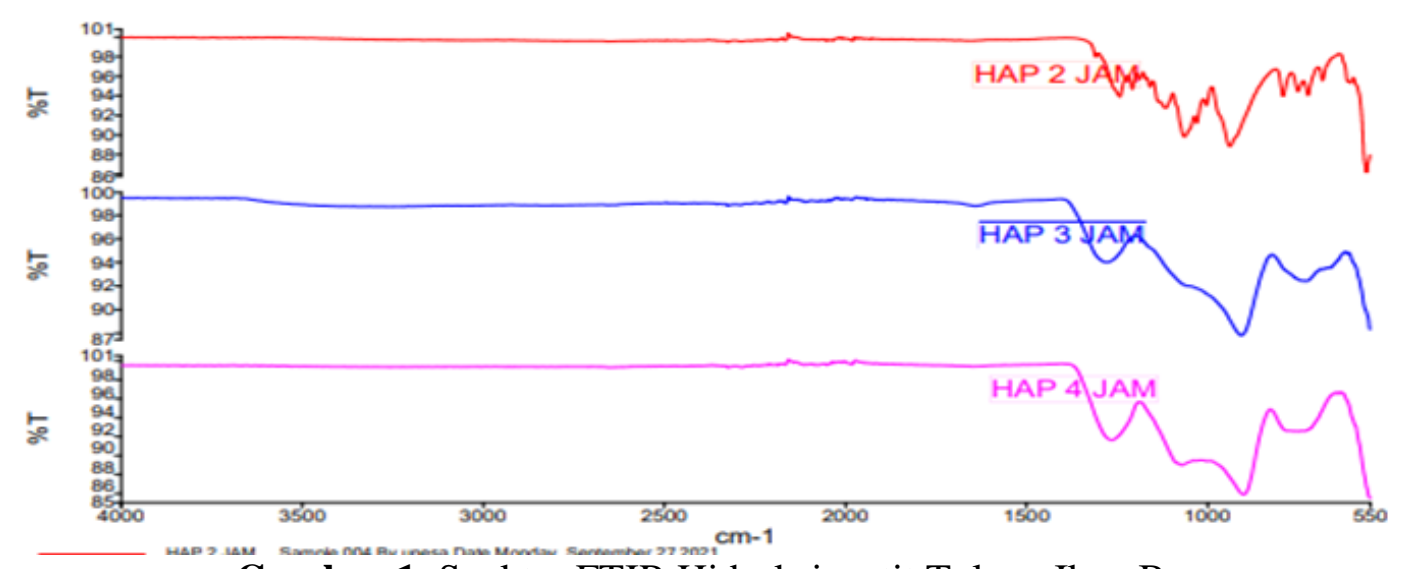

Gambar 1. Spektra FTIR Hidroksiapatit Tulang Ikan Baung

Gambar 1 di atas merupakan spektra FTIR hidroksiapatit tulang ikan Baung, dimana pada ketiga spektra tersebut menunjukkan gugus yang terlihat adalah gugus $\mathrm{PO}_{4}{ }^{3-}$ dan $\mathrm{CO}_{3}{ }^{2-}$. Pada spektra diatas gugus fungsi $\mathrm{CO}_{3}{ }^{2-}$ yang terdapat pada variasi waktu 2 jam ditunjukkan pada bilangan gelombang $1241,47 \mathrm{~cm}^{-1}$ dan $1062,71 \mathrm{~cm}^{-1}$. Sedangkan pada variasi waktu 3 jam ditunjukkan pada bilangan gelombang $1279,13 \mathrm{~cm}^{-1}$. variasi waktu 4 jam ditunjukkan pada bilangan gelombang $1263,28 \mathrm{~cm}^{-1}$. Pembentukan fasa kalsium karbonat terbentuk pada proses kalsinasi yang dilakukan, kalsium pada tulang ikan akan berikatan dengan gugus karbonat hasil kalsinasi (Afifah \& Cahyaningrum,
2020). Gugus $\mathrm{PO}_{4}{ }^{3-}$ pada variasi waktu 2 jam berada pada bilangan gelombang $936,49 \mathrm{~cm}^{-1}, 789,97 \mathrm{~cm}^{-1}$ dan $720,96 \mathrm{~cm}^{-1}$. Sedangkan variasi waktu 3 jam berada pada bilangan gelombang $905,83 \mathrm{~cm}^{-1}$ dan $723,07 \mathrm{~cm}^{-1}$. Sedangkan variasi waktu 4 jam berada pada bilangan gelombang $899,24 \mathrm{~cm}^{-1}$ dan $745,19 \mathrm{~cm}^{-1}$. Menurut Ranamanggala (2020), Gugus $\mathrm{PO}_{4}{ }^{3-}$ pada kisaran 600-420 $\mathrm{cm}^{-1}, 990-950 \mathrm{~cm}^{-1}, 1100$ $1020 \mathrm{~cm}^{-1}$, dan 2200-1990 $\mathrm{cm}^{-1}$ (Ranamanggala, et al., 2020).

Pada hasil FTIR tidak menunjukkan adanya gugus $\mathrm{OH}$ yang merupakan salah satu gugus penyusun Hidroksiapatit. Hal tersebut dikarenakan beberapa aspek, yaitu kalsium hidroksida muncul pada waktu 
penggerusan yang singkat karena hidrasi atmosfer sampel, kemudian menghilang dan profil apatitik muncul secara progresif dengan meningkatnya waktu penggerusan (Mochales, et al., 2011).

Selain itu, peningkatan kristalinitas profil apatitik dengan waktu penggerusan yang lebih tinggi terlihat jelas. Dengan tidak adanya reaksi mekanokimia, diharapkan bahwa waktu penggerusan yang lebih tinggi akan menyebabkan pengurangan ukuran kristal, dan karena itu puncak yang lebih luas. Sebaliknya, dalam hal ini kristalinitas meningkat dengan waktu Penggerusan. Setelah 2 jam Penggerusan, beberapa puncak nonapatitik muncul dan meningkat dengan waktu Penggerusan yang lebih lama. Puncak ini ditujukan ke $\beta$-TCP. terbentuknya $\beta$-TCP mungkin disebabkan oleh efek Penggerusan progresif dari kristal apatit yang sudah terbentuk, yang mendorong dekomposisi parsialnya dengan hilangnya gugus $\mathrm{OH}^{-}$(Mochales, et al., 2011).

Pada penelitian sebelumnya terkait dengan penggunaan tulang ikan sebagai prekursor utama pembentukan

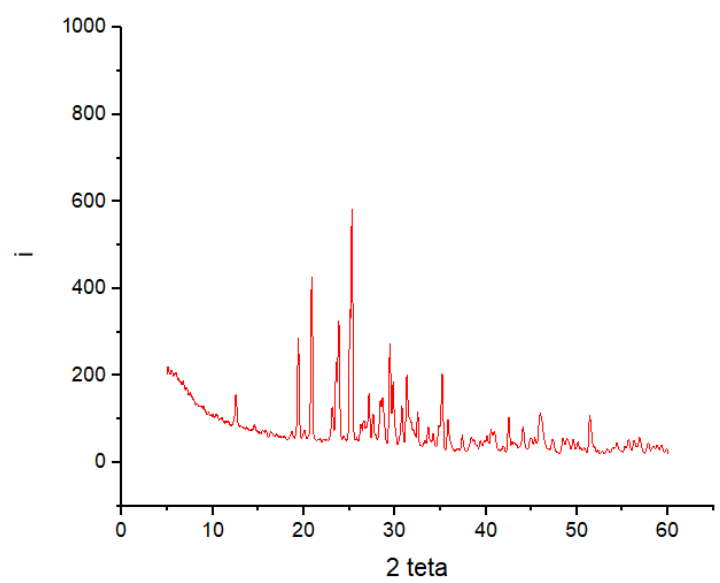

(a) hidroksiapatit menunjukkan hasil FTIR yang sama, yaitu gugus yang muncul adalah $\mathrm{PO}_{4}{ }^{3-}$ dan $\mathrm{CO}_{3}{ }^{-2}$. Spektrum FTIR mulai dari 500 hingga $4000 \quad \mathrm{~cm}-1$ menunjukkan informasi mikro dari fishbone-HAp . Pita pada $725 \mathrm{~cm}^{-1}, 871$ $\mathrm{cm}^{-1}$ dan $962 \mathrm{~cm}^{-1}$ dikaitkan dengan mode vibrasi $\mathrm{PO}_{4}{ }^{3-}$. Puncak kuat pada $1031 \mathrm{~cm}^{-1}$ dan $1415 \mathrm{~cm}^{-1}$ dikaitkan dengan mode getaran peregangan HAp karbonat karena pembentukan $\mathrm{PO}_{4}{ }^{3-}$ oleh $\mathrm{CO}_{3}{ }^{2-}$. Hasil menunjukkan bahwa pembentukan ikatan OePO dari $\mathrm{POe}_{4}{ }^{3-}$ dikaitkan dengan ikatan degenerasi simetris pada getaran $571 \mathrm{~cm}^{-1}$ (Sathiyavima, et al., 2020).

\section{X-Ray Diffraction (XRD)}

Analisis XRD dilakukan untuk mengetahui fasa dan kristalinitas dari sampel. Analisis fasa dilakukan dengan membandingkan puncak $2 \Theta$ pada data XRD dengan data standar yang biasa disebut JCPDS (Database Joint Committe On Powder Diffraction Standards). Hasil XRD berupa difraktogram dengan sudut difraksi (2Ө) dan intensitas (I) sebagai berikut.

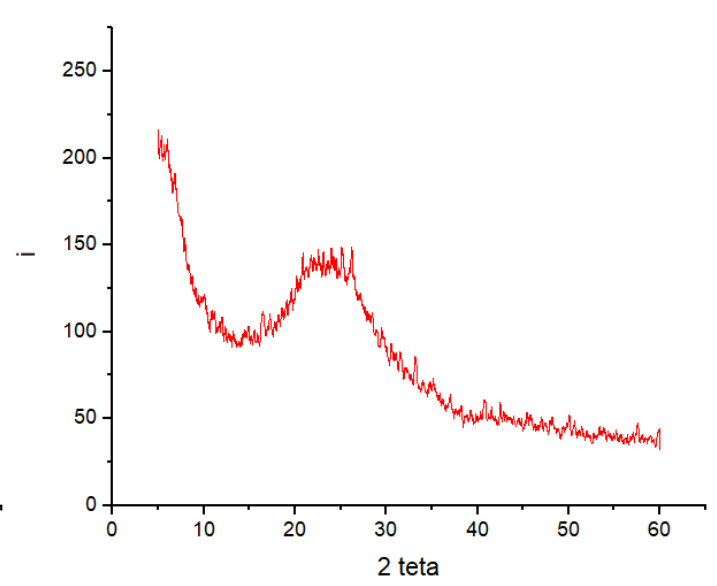

(b) 


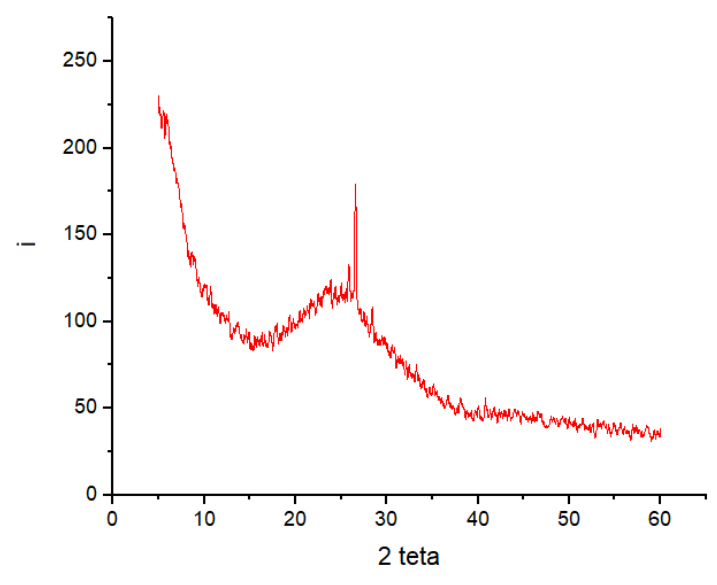

(c)

Gambar 2. Difraktogram Hasil XRD (a) 2 jam (b) 3 jam (c) 4 jam

Gambar 2 memperlihatkan hasil XRD dari 3 variasi waktu kalsinasi hidroksiapatit tulang ikan Baung. Pada variasi waktu 2 jam (Gambar 2a), dapat terlihat puncak difraktrogram tajam diikuti intensitas yang cukup tinggi pada sudut $2 \Theta=25,27^{\circ}$, diikuti dengan puncak lainnya yaitu $29,38^{\circ}$ dan $29,79^{\circ}$. Sedangkan Pada variasi waktu 3 jam (Gambar 2b), dapat terlihat puncak difraktrogram tajam diikuti intensitas yang cukup tinggi pada sudut $2 \Theta=26,20^{\circ}$. Pada variasi waktu 4 jam (Gambar 2c), dapat terlihat puncak difraktrogram tajam diikuti intensitas yang cukup tinggi pada sudut $2 \Theta=26,55^{\circ}$, diikuti oleh puncak lainnya yaitu $25,8^{\circ}$. Dengan merujuk pada JPCDS No. 71-2123 senyawa yang terbentuk adalah kalsium pirofosfat.

Pada variasi waktu 2 jam (Gambar 2a), Terdapat puncak lain pada dif'raktogram tersebut, yaitu pada sudut $2 \Theta=31,29^{\circ}$ dan $32,51^{\circ}$. Sedangkan Pada variasi waktu 3 jam (Gambar 2b), terdapat puncak pada difraktogram tersebut, yaitu pada sudut $2 \Theta=31,46^{\circ}$. Pada variasi waktu 4 jam
(Gambar 2c), terdapat puncak pada difraktogram tersebut, yaitu pada sudut $2 \Theta=28,42^{\circ}, \quad 31,59^{\circ}$ dan 52,95 . Jika merujuk pada JPCDS No. 03-0747 senyawa yang terbentuk adalah hidroksiapatit.

\section{Kesimpulan}

Dari penelitian yang dilakukan, dapat diambil kesimpulan tulang ikan Baung berpotensi menjadi prekursor material pembentukan hidroksiapatit. Hasil XRD yang menunjukkan karakteristik fisika tulang ikan Baung menunjukkan sintesis hidroksiapatit tulang ikan Baung memperoleh kristalinitas sebesar 85,6\%, $63,45 \%$, dan $74,24 \%$. Variasi waktu yang menunjukkan kualitas intensitas terbaik terlihat pada variasi waktu 2 jam yang ditunjukkan oleh difraktogram XRD. Serta hasil karakterisasi secara kimia menunjukkan munculnya gugus $\mathrm{PO}_{4}{ }^{3-}$ dan $\mathrm{CO}_{3}{ }^{2-}$. Kedua gugus tersebut termasuk dalam gugus yang dimiliki oleh hidroksiapatit. 


\section{Daftar Pustaka}

Afifah, F. \& Cahyaningrum, S. E., 2020. Sintesis Dan Karakterisasi Hidroksiapatit Dari Tulang Sapi (Bos Taurus) Menggunakan Teknik Kalsinasi. Unesa Journal of Chemistry, 9(3), pp. 189-196.

Amin, A. \& Ulfah, M., 2017. Sintesis Dan Karakterisasi Komposit Hidroksiapatit Dari Tulang Ikan Lamuru (Sardilnella Longiceps) Kitosan Sebagai Bone Filler. Jurnal Farmasi FIK Uinam, 5(1), pp. 9-15.

Anggresani, L., Perawati, S. \& Rahayu, I. J., 2019. Limbah Tulang Ikan Tenggiri (Scomberomorus Guttatus) Sebagai Sumber Kalsium Pada Pembuatan Hidroksiapatit. Jurnal Katalisator, 4(2), pp. 133-140.

Anjarsari, Dahlan, K., Suptijah, P. \& Kemala, T., 2016. Sintesis Dan Karakterisasi Biokomposit BCP / Kolagen Sebagai Material Perancah Tulang. JPHPI, 19(3), pp. 356-361.

Esmaeilkhanian, A. et al., 2019. Synthesis and Characterization of Natural Nanohydroxyapatite Derived from Turkey Femur-Bone Waste. Applied Biochemistry and Biotechnology , Volume 189, pp. 919-932.

Haruda, M. S., Fadli, A. \& Yenti, S. R., 2016. Pengaruh Ph Dan Waktu Reaksi Pada Sintesis Hidroksiapatit Dari Tulang Sapi Dengan Metode Presipitasi. Jom FTEKNIK, 3(1), pp. 1-7.

Kim, S., Lee, G. S., Shrout, T. R. \& Venkataramani, S., 1991. Fabrication of fine-grain piezoelectric ceramics using reactive calcination. Journal of Materials Science, pp. 4411-4415.

Komari, N., Irawati, U. \& Novita, E., 2013. Kandungan Kadmium Dan Seng Pada Ikan Baung (Hemibagrus nemurus) Di Perairan Trisakti Banjarmasin Kalimantan Selatan. Sains dan Terapan Kimia, 7(1), pp. 42-49.

Marliana, A. et al., 2015. Synthesis and characterization of hydroxyapatite from fish bone waste. American
Institute of Physic, Volume 1699, p. 040006.

Mochales, C., Wilson, R. M., Dowker, S. E. P. \& Ginebra, M. P., 2011. Dry mechanosynthesis of nanocrystalline calcium deficient hydroxyapatite: Structural characterisation. Journal of Alloys and Compounds, Volume 509, pp. 7389-7394.

Nurmanta, D. A., Masruroh \& Santjojo, D. D., 2021. Perbaikan Nilai Kuat Tekan Biokeramik Scaffold Hidroksiapatit Menggunakan Treatment Plasma DBD. Jurnal Qua Teknika, 11(1), pp. 1-9.

Rahmawati, D., Sunarso \& Irawan, B., 2020. Aplikasi Hidroksiapatit Sebagai Bone Filler Pasca Pencabutan Gigi. Jurnal Material Kedokteran, 9(2), pp. 39-46.

Ranamanggala, et al., 2020. Potensi Hidroksiapatit Dari Tulang Ayam Sebagai Pelapis Implan Gigi. Jurnal Kimia Riset, 5(2), pp. 141-150.

Saleha, et al., 2015. Sintesis Dan Karakterisasi Hidroksiapatit Dari Nanopartikel Kalsium Oksida (CaO) Cangkang Telur Untuk Aplikasi Dental Implan. Yogyakarta: Prosiding Pertemuan Ilmiah XXIXHFI Jateng \& DIY.

Sathiyavima, S. et al., 2020. Facile synthesis and characterization of hydroxyapatite from fish bones: Photocatalytic degradation of industrial dyes (crystal violet and Congo red). Progress in Organic Coatings, Volume 148, p. 105890.

Sidiqa, A. N., Djustiana, N., Sunendar, B. \& Febrida, R., 2012. Surface Modification Of Multilaver Coayings Ti-Al-Cr And Hydroxyapatite On Calcium Phospate Cement With SolGel Metho. Journal of Density Indonesia, 19(2), pp. 43-46.

Sulistioso, G. S., Deswita, Wulanawati, A. \& Romawati, A., 2012. Sintesis Hidroksiapatit Berpori dengan Porogen Kitosan Dan 
Karakterisasinya. Jurnal Kimia Kemasan, 34(1), pp. 220-225.

Sumarto, et al., 2021. Characteristic Of Nano-Calcium Bone From A Different Species of Catfish(Pangasius Hypophthalmus, Clarias Batrachus, Hemibagrus Nemurusand Paraplotosus Albilabris). Riau: Earth and Environmental Science.

Surya, P., Nithin, A., Sundaramanickam, R. \& Sathish, M., 2021. Synthesis and characterization of nanohydroxyapatite from Sardinella longiceps fish bone and its effects on human osteoblast bone cells. Journal of the Mechanical Behavior of Biomedical Materials, Volume 119, p. 104501.
Trilaksani, W., Salamah, E. \& Nabil, M., 2006. Pemanfaatan Limbah Tulang Ikan Tuna (Thunnus sp) Sebagai Sumber Kalsium Dengan Metode Hidrolisis Protein. JPHPI, 9(2), pp. 34-45.

Wahdah, I., Wardhani, S. \& Darjito, 2014. Sintesis Hidroksiapatit Dari Tulang Sapi Dengan Metode Basah Pengendapan. Kimia Student Journal, 1(1), pp. 92-97.

Zein, U. R., Anggresani, L. \& Yulianis, 2020. Pengaruh Waktu Sintering Terhadap Hidroksiapatit Berpori Tulang Ikan Tenggiri Dengan Proses Sol-Gel. Chempublish Journal, 5(1), pp. $46-56$. 